\title{
Synthesis and Anticancer Activity of New 2-Aryl-4-(4- Methoxybenzylidene)-5-Oxazolone Scaffolds
}

\author{
Ahmed A. Fadda ${ }^{1(\mathbb{D})}$, Raaben M. Mohammed ${ }^{1(\mathbb{D})}$, Eman H. Tawfik ${ }^{1(\mathbb{D})}$, \\ Mamdouh A. A. Hammouda 2,* (D) \\ 1 Department of Chemistry, Faculty of Science, Mansoura University, 35516 Mansoura, Egypt \\ 2 Natural and Microbial Products Department, Pharmaceutical and Drug Industries Research Division, National Research \\ Centre (NRC), Egypt \\ * Correspondence: mamhamm66@gmail.com;
}

Scopus Author ID 56490376500

Received: 26.06.2020; Revised: 14.07.2020; Accepted: 15.07.2020; Published: 18.07.2020

\begin{abstract}
A new series of 4-(4-methoxybenzylidene)-2-substitutedphenyl-5(4H)-oxazolone derivatives has been synthesized through the application of Erlenmeyer condition $\left(\mathrm{Ac}_{2} \mathrm{O}, \mathrm{AcONa}\right.$, and 4-anisaldehyde) to the reaction products of the highly versatile p-aminohippuric acid with various electrophilic reagents such as aromatic aldehydes, phenyl isothiocyanate, diazotization-coupling reaction (malononitrile and 2-amino-4-phenylthiazole) and cyanoacetyl-pyrazole. IR, ${ }^{1} \mathrm{H}$ NMR, and mass spectroscopic techniques were utilized to confirm the structures of these oxazolone scaffolds. The synthesized oxazolone derivatives were evaluated against four human cancer cell lines (HepG2, HTC116, PC-3, and MCF-7). Compound $\mathbf{3 e}$ showed the best activity against hepatocellular carcinoma ( $\mathrm{IC}_{50}$ $8.9 \pm 0.30 \mu \mathrm{g} / \mathrm{mL}$ ) and colorectal carcinoma ( $\mathrm{IC}_{50} 9.2 \pm 0.63 \mu \mathrm{g} / \mathrm{mL}$ ) cell lines compared with the standard anticancer drug 5-fluorouracil.
\end{abstract}

Keywords: p-Aminohippuric acid; acetic anhydride; Erlenmeyer reaction; diazo coupling; malononitrile.

(C) 2020 by the authors. This article is an open-access article distributed under the terms and conditions of the Creative Commons Attribution (CC BY) license (https://creativecommons.org/licenses/by/4.0/).

\section{Introduction}

Oxazole derivatives have been utilized as important precursors for the construction of many biologically active compounds as antimicrobial agents [1], photosensitive composition devices for proteins [2], and biosensors in the detection of ACh inhibitor [3]. Oxazole-based compounds could readily bind with a variety of enzymes and receptors in biological systems and show broad biological activities [4-13]. Especially, the 4-arylidene-5(4H)-oxazolones are important precursors for the construction of many organic molecules such as amino acids and peptides [14]. They display a broad domain of pharmacological activities [15-20], such as antiinflammatory [21], anticancer [22], antagonistic and antiangiogenic [23,24] and tyrosinase inhibitor [25]. As a result of the synthesis of various substituted oxazolones is highly desirable, a number of synthetic protocols [26-29] have been reported for the preparation of azlactones. These include the utilization of acetic anhydride with sodium(lead) acetate, sulfur trioxide/dimethylformamide complex, polyphosphoric acid and perchloric acid, in addition to the methods that employ triphenylphosphonium chloride $\left(\mathrm{Ph}_{3} \mathrm{P} / \mathrm{CCl}_{4}\right)$, anhydrous zinc chloride or bismuth (III) acetate as catalysts [30-35]. In light of an urgent need to develop anticancer materials, recent research papers have been published to diminish the growth of tumor cells by cytotoxic agents [36,37]. The present research article reports on the preparation of some new 
oxazolone scaffolds, their structures elucidation by IR, ${ }^{1} \mathrm{H}$ NMR \& MS spectroscopic techniques, and evaluating their anticancer activity.

\section{Materials and Methods}

All melting points were measured on the Gallenkamp electric melting point apparatus. Infrared spectra were determined on Mattson $5000 \mathrm{FT}$-IR spectrometer ( $\mathrm{KBr}$ discs). The $1 \mathrm{H}$ NMR spectra were recorded on a Varian XL $300 \mathrm{MHz}$ apparatus. The Mass spectra were performed using a Shimadzu Qp-2010 mass spectrometer at $70 \mathrm{eV}$ (EI mode). Elemental analyses $(\mathrm{C}, \mathrm{H}$, and $\mathrm{N})$ were determined on Perkin-Elmer 2400 analyzer.

\subsection{Synthesis of (4-arylideneamino-benzoyl)-glycines $2 a-e$.}

A mixture of 4-aminohippuric acid $(0.97 \mathrm{~g}, 0.005 \mathrm{~mol})$ and the appropriate aromatic aldehyde $(0.005 \mathrm{~mol})$ in $20 \mathrm{~mL}$ distilled ethyl alcohol was boiled under reflux for 4 hours. The precipitate that formed upon cooling was filtered to afford glycine derivatives $2 \mathbf{a}-\mathbf{e}$.

(4-Benzylideneamino-benzoyl)-glycine (2a). White crystals in $63 \%$ yield; m.p. $=218-220{ }^{\circ} \mathrm{C}$; IR: $3318(\mathrm{NH}, \mathrm{OH}), 1744 \mathrm{~cm}^{-1}$ (broad, $\left.\mathrm{C}=\mathrm{O}\right) ;{ }^{1} \mathrm{H}$ NMR $\left(\mathrm{CDCl}_{3}\right): \delta / \mathrm{ppm}=12.35(\mathrm{~s}, 1 \mathrm{H}), 10.15$ $(\mathrm{s}, 1 \mathrm{H}), 8.25(\mathrm{~s}, 1 \mathrm{H}), 7.80-7.35(\mathrm{~m}, 9 \mathrm{H}), 3.65(\mathrm{~d}, J=4.80 \mathrm{~Hz}, 2 \mathrm{H})$; Analysis for $\mathrm{C}_{16} \mathrm{H}_{14} \mathrm{~N}_{2} \mathrm{O}_{3}$ (282.30): Calcd. C, 68.08; H, 5.00; N, 9.92\%. Found: C, 68.27; H, 5.05; N, 9.84\%.

[4-(4-Methylbenzylidene-amino)-benzoyl]-glycine (2b). White crystals in $73 \%$ yield; m.p. = 196-198 ${ }^{\circ} \mathrm{C}$; IR: $3339(\mathrm{NH}, \mathrm{OH}), 1734(\mathrm{C}=\mathrm{O}), 1642 \mathrm{~cm}^{-1}(\mathrm{C}=\mathrm{O}) ; 1 \mathrm{H} \mathrm{NMR}\left(\mathrm{CDCl}_{3}\right)$ : $\delta / \mathrm{ppm}=12.30(\mathrm{~s}, 1 \mathrm{H}), 10.25(\mathrm{~s}, 1 \mathrm{H}), 8.25(\mathrm{~s}, 1 \mathrm{H}), 7.80-7.25(\mathrm{~m}, 8 \mathrm{H}), 3.65(\mathrm{~d}, J=4.80 \mathrm{~Hz}$, 2H), 2.35 (s, 3H); Analysis for $\mathrm{C}_{17} \mathrm{H}_{16} \mathrm{~N}_{2} \mathrm{O}_{3}$ (296.33): Calcd. C, 68.91; H, 5.44; N, 9.45\%. Found: C, 68.73; H, 5.48; N, 9.52\%.

[4-(4-Nitrobenzylidene-amino)-benzoyl]-glycine (2c). Yellow powder in $62 \%$ yield; m.p. $=216-218^{\circ} \mathrm{C}$; IR: $3436(\mathrm{NH}, \mathrm{OH}), 1730(\mathrm{C}=\mathrm{O}), 1654 \mathrm{~cm}^{-1}(\mathrm{C}=\mathrm{O}) ;{ }^{1} \mathrm{H}$ NMR (DMSO- $\left.d_{6}\right)$ : $\delta / \mathrm{ppm}=12.87(\mathrm{~s}, 1 \mathrm{H}), 11.08(\mathrm{~s}, 1 \mathrm{H}), 8.44(\mathrm{~s}, 1 \mathrm{H}), 8.16-7.30(\mathrm{~m}, 8 \mathrm{H}), 3.68(\mathrm{~d}, J=4.80 \mathrm{~Hz}$, $2 \mathrm{H}$ ); MS: $\mathrm{m} / \mathrm{z}(\%)=327$ (molecular ion peak, 23), 58 (base peak, 100); Analysis for $\mathrm{C}_{16} \mathrm{H}_{13} \mathrm{~N}_{3} \mathrm{O} 5$ (327.30): Calcd. C, 58.72; H, 4.00; N, 12.84\%. Found: C, 58.54; H, 3.94; N, $12.67 \%$.

[4-(4-Chlorobenzylidene-amino)-benzoyl]-glycine (2d). Light brown crystals in 55\% yield; m.p. $=191-192{ }^{\circ} \mathrm{C}$; IR: $3294(\mathrm{NH}, \mathrm{OH}), 1709(\mathrm{C}=\mathrm{O}), 1644 \mathrm{~cm}^{-1}(\mathrm{C}=\mathrm{O}) ;{ }^{1} \mathrm{H}$ NMR $\left(\mathrm{CDCl}_{3}\right)$ : $\delta / \mathrm{ppm}=12.35(\mathrm{~s}, 1 \mathrm{H}), 10.15(\mathrm{~s}, 1 \mathrm{H}), 8.45(\mathrm{~s}, 1 \mathrm{H}),, 7.90-7.30(\mathrm{~m}, 8 \mathrm{H}), 3.58(\mathrm{~d}, J=4.60 \mathrm{~Hz}$, $2 \mathrm{H}$ ); Analysis for $\mathrm{C}_{16} \mathrm{H}_{13} \mathrm{ClN}_{2} \mathrm{O}_{3}$ (316.74): Calcd. C, 60.67; H, 4.14; N, 8.84\%. Found: C, $60.78 ; \mathrm{H}, 4.08 ; \mathrm{N}, 8.91 \%$.

[4-(4-Chloro-2-nitrobenzylidene-amino)-benzoyl]-glycine (2e). Orange crystals in $78 \%$ yield; m.p. $=270-272{ }^{\circ} \mathrm{C}$; IR: $3262(\mathrm{NH}, \mathrm{OH}), 1701(\mathrm{C}=\mathrm{O}), 1653 \mathrm{~cm}^{-1}(\mathrm{C}=\mathrm{O}) .{ }^{1} \mathrm{H}$ NMR $\left(\mathrm{DMSO}-d_{6}\right): \delta / \mathrm{ppm}=12.35(\mathrm{~s}, 1 \mathrm{H}), 10.05(\mathrm{~s}, 1 \mathrm{H}), 8.45(\mathrm{~s}, 1 \mathrm{H}), 7.80-8.15(\mathrm{~m}, 7 \mathrm{H}), 3.61(\mathrm{~d}, J$ $=4.80 \mathrm{~Hz}, 2 \mathrm{H}$ ); Analysis for: $\mathrm{C}_{16} \mathrm{H}_{12} \mathrm{ClN}_{3} \mathrm{O}_{5}$ (361.74): Calcd. C, 53.13; H, 3.34; N, $11.62 \%$. Found: C, 53.05; H, 3.31; N, 11.70\%.

2.2. Synthesis of 2-(4-arylideneamino-phenyl)-4-(4-methoxy-benzylidene)-oxazol-5(4H)-one derivatives $3 a-e$.

A mixture of anhydrous sodium acetate $(0.16 \mathrm{~g}, 0.002 \mathrm{~mol}), \mathrm{p}$-anisaldehyde $(0.27 \mathrm{~mL}$, $0.002 \mathrm{~mol})$ and (4-(arylideneamino)-benzoyl)-glycines 2a-e $(0.002 \mathrm{~mol})$ in acetic anhydride 
(20 mL) was heated with stirring at $100{ }^{\circ} \mathrm{C}$ for 4 hours. The reaction mixture was poured into ice-water, and the precipitate that formed was filtered and recrystallized from ethanol.

2-(4-Benzylideneamino-phenyl)-4-(4-methoxybenzylidene)-oxazol-5(4H)-one (3a). Yellow powder in 38\% yield; m.p. $=248-250{ }^{\circ} \mathrm{C}$; IR: $1793(\mathrm{C}=\mathrm{O}), 1652 \mathrm{~cm}^{-1}(\mathrm{C}=\mathrm{N}) ;{ }^{1} \mathrm{H}$ NMR $\left(\mathrm{DMSO}-d_{6}\right): \delta / \mathrm{ppm}=8.31(\mathrm{~s}, 1 \mathrm{H}), 8.22(\mathrm{~s}, 1 \mathrm{H}), 7.75-7.24(\mathrm{~m}, 13 \mathrm{H}), 3.78(\mathrm{~s}, 3 \mathrm{H})$; Analysis for $\mathrm{C}_{24} \mathrm{H}_{18} \mathrm{~N}_{2} \mathrm{O}_{3}$ (382.42): Calcd. C, 75.38; H, 4.74; N, 7.33\%. Found: C, 75.18; H, 4.68; N, 7.21\%.

4-(4-Methoxybenzylidene)-2-[4-(4-methylbenzylideneamino)-phenyl]-oxazol-5(4H)-

one $(\mathbf{3 b})$. Brown powder in 34\% yield; m.p. $=214-215^{\circ} \mathrm{C}$. IR: $1761(\mathrm{C}=\mathrm{O}), 1646 \mathrm{~cm}^{-1}(\mathrm{C}=\mathrm{N})$; ${ }^{1} \mathrm{H}$ NMR (DMSO-d6): $\delta / \mathrm{ppm}=8.35(\mathrm{~s}, 1 \mathrm{H}), 8.10(\mathrm{~s}, 1 \mathrm{H}), 7.83-7.20(\mathrm{~m}, 12 \mathrm{H}), 3.78(\mathrm{~s}, 3 \mathrm{H})$, 2.35 (s, 3H); Analysis for $\mathrm{C}_{25} \mathrm{H}_{20} \mathrm{~N}_{2} \mathrm{O}_{3}$ (396.45): Calcd. C, 75.74; H, 5.09; N, 7.07\%. Found: C, 75.56; H, 5.15; N, 7.00\%.

4-(4-Methoxybenzylidene)-2-[4-(4-nitrobenzylideneamino)phenyl]-oxazol-5(4H)-one (3c). Yellowish brown powder in 38\% yield; m.p. $=263-264{ }^{\circ} \mathrm{C}$; IR: broad centered at 1713 $(\mathrm{C}=\mathrm{O}), 1645 \mathrm{~cm}^{-1}(\mathrm{C}=\mathrm{N}) ;{ }^{1} \mathrm{H}$ NMR (DMSO- $\left.d_{6}\right): \delta / \mathrm{ppm}=8.48(\mathrm{~s}, 1 \mathrm{H}), 8.22(\mathrm{~s}, 1 \mathrm{H}), 8.12-7.08$ $(\mathrm{m}, 12 \mathrm{H}), 3.81(\mathrm{~s}, 3 \mathrm{H}) ; \mathrm{MS}: \mathrm{m} / \mathrm{z}(\%)=427$ (molecular ion peak, 1.95), 84 (base peak, 100); Analysis for $\mathrm{C}_{24} \mathrm{H}_{17} \mathrm{~N}_{3} \mathrm{O}_{5}$ (427.42): Calcd. C, 67.44; H, 4.01; N, 9.83\%. Found: C, 67.59; H, $4.08 ; \mathrm{N}, 9.77 \%$.

2-[4-(4-Chlorobenzylideneamino)phenyl]-4-(4-methoxy-benzylidene)-oxazol-5(4H)one $(\mathbf{3 d})$. Yellowish green powder in 30\% yield; m.p. $=205-207^{\circ} \mathrm{C}$; IR: $1790(\mathrm{C}=\mathrm{O}), 1657 \mathrm{~cm}-$ $1(\mathrm{C}=\mathrm{N}) ; 1 \mathrm{H}$ NMR $\left(\mathrm{DMSO}-d_{6}\right): \delta / \mathrm{ppm}=8.41(\mathrm{~s}, 1 \mathrm{H}), 7.98(\mathrm{~s}, 1 \mathrm{H}), 7.85-7.11(\mathrm{~m}, 12 \mathrm{H}), 3.82$ (s, 3H); MS: m/z (\%) = 416 (molecular ion peak, 37), 162 (base peak, 100); Analysis for $\mathrm{C}_{24} \mathrm{H}_{17} \mathrm{ClN}_{2} \mathrm{O}_{3}$ (416.86): Calcd. C, 69.15; H, 4.11; N, 6.72\%. Found: C, 69.32; H, 4.07; N, $6.64 \%$.

2-[4-(4-Chloro-2-nitrobenzylideneamino)phenyl]-4-(4-methoxybenzylidene)-oxazol$5(4 H)$-one (3e). Yellow powder in $46 \%$ yield; m.p. > $300{ }^{\circ} \mathrm{C}$; IR: $1796(\mathrm{C}=\mathrm{O}), 1655 \mathrm{~cm}^{-1}$ $(\mathrm{C}=\mathrm{N}) ;{ }^{1} \mathrm{H}$ NMR (DMSO- $\left.d_{6}\right): \delta / \mathrm{ppm}=8.67(\mathrm{~s}, 1 \mathrm{H}), 8.42-7.14(\mathrm{~m}, 12 \mathrm{H}), 3.81(\mathrm{~s}, 3 \mathrm{H}) ; \mathrm{MS}: \mathrm{m} / \mathrm{z}$ $(\%)=461$ (molecular ion peak, 40), 120 (base peak, 100); Analysis for $\mathrm{C}_{24} \mathrm{H}_{16} \mathrm{ClN}_{3} \mathrm{O}_{5}$ (461.86): Calcd. C, 62.41; H, 3.49; N, 9.10\%. Found: C, 62.31; H, 3.43; N, 9.19\%.

2.3. Synthesis of 4-(4-methoxybenzylidene)-2-(4-N'-phenyl-thioureido-phenyl)-oxazol-5(4H)one (5).

A mixture of anhydrous sodium acetate $(0.16 \mathrm{~g}, 0.002 \mathrm{~mol})$ and $p$-anisaldehyde $(0.27$ $\mathrm{ml}, 0.002 \mathrm{~mol})$ and phenylthiourea derivative $4(0.66 \mathrm{~g}, 0.002 \mathrm{~mol})$ in acetic anhydride $(20 \mathrm{~mL})$ was heated with stirring at $100{ }^{\circ} \mathrm{C}$ for 4 hours. After cooling, the reaction mixture was poured into ice-cold water. Then, the resulting solid was filtered and recrystallized by heating in ethanol to give 5. Light brown crystals in $42 \%$ yield; m.p. $=169-171^{\circ} \mathrm{C}$; IR: broad centered at $3387(\mathrm{NH}), 1781(\mathrm{C}=\mathrm{O}), 1652 \mathrm{~cm}^{-1}(\mathrm{C}=\mathrm{N}) ;{ }^{1} \mathrm{H}$ NMR (DMSO- $\left.d_{6}\right): \delta / \mathrm{ppm}=13.25(\mathrm{~s}, 1 \mathrm{H}), 11.75$ $(\mathrm{s}, 1 \mathrm{H}), 7.95-7.24(\mathrm{~m}, 14 \mathrm{H}), 3.79(\mathrm{~s}, 3 \mathrm{H}) ; \mathrm{MS}: \mathrm{m} / \mathrm{z}(\%)=429$ (molecular ion peak, 28.35), 77 (base peak, 100). Analysis for $\mathrm{C}_{24} \mathrm{H}_{19} \mathrm{~N}_{3} \mathrm{O}_{3} \mathrm{~S}$ (429.49): Calcd. C, 67.12; H, 4.46; N, 9.78\%. Found: C, 67.32; H, 4.55; N, 9.65\%.

\subsection{Synthesis of 4-[2-(dicyanomethylene)hydrazinyl]benzoyl-glycine (7).}

4-Aminohippuric acid (0.97 g, $0.005 \mathrm{~mol})$ was firstly neutralized by stirring with 15 $\mathrm{mL} \mathrm{Na} 2 \mathrm{CO}_{3}$ solution $(2.5 \%)$, and the solution that obtained was cooled to $0-5^{\circ} \mathrm{C}$. Sodium nitrite $(0.35 \mathrm{~g})$ was added to this neutralized solution with stirring. Then the solution was acidified by 
conc. $\mathrm{HCl}(1.5 \mathrm{~mL})$ and then water $(1.5 \mathrm{~mL} \mathrm{H} 2 \mathrm{O})$ was added. The freshly prepared suspension of the diazonium chloride was added drop by drop with stirring to a cold solution of malononitrile $(0.33 \mathrm{~g}, 0.005 \mathrm{~mole})$ and $1.5 \mathrm{~g}$ sodium acetate in $30 \mathrm{~mL}$ EtOH. After stirring the reaction mixture for 3 hours at $0-5^{\circ} \mathrm{C}$, the resulting precipitate was filtered and recrystallized from ethyl alcohol. Orange powder in 76\% yield; m.p. $=145-146^{\circ} \mathrm{C}$, lit. m.p. $=144-147^{\circ} \mathrm{C}$ [1]; IR: 3395, $3222(\mathrm{NH}, \mathrm{OH}), 2226(\mathrm{C} \equiv \mathrm{N}), 1753(\mathrm{C}=\mathrm{O}), 1637 \mathrm{~cm}^{-1}(\mathrm{C}=\mathrm{N}) ;{ }^{1} \mathrm{H} \mathrm{NMR}\left(\mathrm{CDCl}_{3}\right)$ : $\delta / \mathrm{ppm}=12.25(\mathrm{~s}, 1 \mathrm{H}), 11.10(\mathrm{~s}, 1 \mathrm{H}), 8.90(\mathrm{~s}, 1 \mathrm{H}), 7.95(\mathrm{~d}, J=8.80 \mathrm{~Hz}, 2 \mathrm{H}), 7.70(\mathrm{~d}, J=8.80$ $\mathrm{Hz}, 2 \mathrm{H}), 3.68$ (d, $J=4.40 \mathrm{~Hz}, 2 \mathrm{H}$ ); Analysis for $\mathrm{C}_{12} \mathrm{H}_{9} \mathrm{~N}_{5} \mathrm{O}_{3}$ (271.24): Calcd. C, 53.14; H, 3.34; N, 25.82\%. Found: C, 53.03; H, 3.29; N, 25.86\%.

2.5. Synthesis of 2-[4-(dicyanomethylene-hydrazinyl)-phenyl]-4-(4-methoxybenzylidene)oxazol-5(4H)-one $(8)$.

A mixture of $7(0.54 \mathrm{~g}, 0.002 \mathrm{~mol})$, with anhydrous sodium acetate $(0.16 \mathrm{~g}, 0.002 \mathrm{~mol})$ and p-anisaldehyde $(0.27 \mathrm{~mL}, 0.002 \mathrm{~mol})$ in acetic anhydride $(15 \mathrm{~mL})$ was heated with stirring at $100^{\circ} \mathrm{C}$ for 4 hours. After cooling, the reaction mixture was poured on ice-cold water. Then, the solid that formed was picked up by filtration and purified by recrystallization from EtOH. Orange powder in $35 \%$ yield; m.p. $=250-252^{\circ} \mathrm{C}$; IR: $3226(\mathrm{NH}), 2224(\mathrm{C} \equiv \mathrm{N}), 1788(\mathrm{C}=\mathrm{O})$, $1688 \mathrm{~cm}^{-1}(\mathrm{C}=\mathrm{N}) ;{ }^{1} \mathrm{H}$ NMR (DMSO- $\left.d_{6}\right): \delta / \mathrm{ppm}=10.58(\mathrm{~s}, 1 \mathrm{H}), 7.96-7.13(\mathrm{~m}, 9 \mathrm{H}), 3.86(\mathrm{~s}$, $3 \mathrm{H}$ ); Analysis for $\mathrm{C}_{20} \mathrm{H}_{13} \mathrm{~N}_{5} \mathrm{O}_{3}$ (371.36): Calcd. C, 64.69; H, 3.53; N, 18.86\%. Found: C, 64.85; $\mathrm{H}, 3.49 ; \mathrm{N}, 18.75 \%$.

\subsection{Synthesis of 4-[(2-amino-4-phenylthiazol-5-yl)azo]benzoyl-glycine (10).}

4-Aminohippuric acid (0.97 g, $0.005 \mathrm{~mol})$ was firstly neutralized by stirring with 15 $\mathrm{mL} \mathrm{Na} 2 \mathrm{CO}_{3}$ solution $(2.5 \%)$, and the solution that obtained was cooled to $0-5^{\circ} \mathrm{C}$. Sodium nitrite $(0.35 \mathrm{~g})$ was added to this neutralized solution with stirring. Then the solution was acidified by conc. $\mathrm{HCl}(1.5 \mathrm{~mL})$ and then water $\left(1.5 \mathrm{~mL} \mathrm{H}_{2} \mathrm{O}\right)$ was added. The freshly prepared suspension of the diazonium chloride was added drop by drop with stirring to a cold solution of 2-amino4-phenylthiazole (9) (0.88 g, 0.005 mole) and $1.5 \mathrm{~g}$ sodium acetate in $30 \mathrm{~mL}$ EtOH. After stirring of the reaction mixture for 3 hours at $0-5^{\circ} \mathrm{C}$, the resulting precipitate was filtered purified by recrystallization from EtOH/DMF mixture (3:1). Dark red crystals in $80 \%$ yield; m.p. > $300{ }^{\circ} \mathrm{C}$; IR: 3402, $3337(\mathrm{NH} 2, \mathrm{NH}, \mathrm{OH})$, broad centered at $1627 \mathrm{~cm}-1(\mathrm{C}=\mathrm{O})$; $1 \mathrm{H} \mathrm{NMR}$ $\left(\left(\mathrm{DMSO}-d_{6}\right)\right): \delta / \mathrm{ppm}=12.15(\mathrm{~s}, 1 \mathrm{H}), 9.84(\mathrm{~s}, 1 \mathrm{H}), 8.05-7.30(\mathrm{~m}, 11 \mathrm{H}), 3.66(\mathrm{~d}, J=4.40 \mathrm{~Hz}$, 2H); MS: m/z $(\%)=381$ (molecular ion peak, 60), 176 (base peak, 100); Analysis for $\mathrm{C}_{18} \mathrm{H}_{15} \mathrm{~N}_{5} \mathrm{O}_{3} \mathrm{~S}$ (381.41): Calcd. C, 56.68; H, 3.96; N, 18.36\%. Found: C, 56.44; H, 3.91; N, $18.29 \%$.

2.7. Synthesis of 2-[4-(2-acetylamino-4-phenylthiazol-5-yl)azo-phenyl]-4-(4-methoxybenzylidene)oxazol-5(4H)-one (11).

A mixture of anhydrous sodium acetate $(0.16 \mathrm{~g}, 0.002 \mathrm{~mol}), p$-anisaldehyde $(0.27 \mathrm{ml}$, $0.002 \mathrm{~mol})$ and 2-amino-5-arylazothiazole derivative $10(0.76 \mathrm{~g}, 0.002 \mathrm{~mol})$ in acetic anhydride $\left(20 \mathrm{~mL}\right.$ ) was heated with stirring at $100{ }^{\circ} \mathrm{C}$ for 4 hours. The reaction mixture was poured into ice cold water. Then, the solid that obtained was picked up by filtration and purified by recrystallization from EtOH. Brown powder in 66\% yield; m.p. $=279-281{ }^{\circ} \mathrm{C}$; IR: $3162(\mathrm{NH})$, $1772(\mathrm{C}=\mathrm{O}), 1684(\mathrm{C}=\mathrm{O}), 1651 \mathrm{~cm}^{-1}(\mathrm{C}=\mathrm{N}) ;{ }^{1} \mathrm{H}$ NMR $\left(\mathrm{DMSO}-d_{6}\right): \delta / \mathrm{ppm}=12.68(\mathrm{~s}, 1 \mathrm{H})$, 
8.24-7.21 (m, 14H), $3.80(\mathrm{~s}, 3 \mathrm{H}), 2.23$ (s, 3H); Analysis for $\mathrm{C}_{28} \mathrm{H}_{21} \mathrm{~N}_{5} \mathrm{O}_{4} \mathrm{~S}$ (523.57): Calcd. C, 64.23; H, 4.04; N, 13.38\%. Found: C, 64.05; H, 4.11; N, $13.27 \%$.

\subsection{Synthesis of 4-(2-cyanoacetamido)benzoyl-glycine (13).}

A suspension of 4-aminohippuric acid (0.97 $\mathrm{g}, 0.005 \mathrm{~mol})$ and 3,5-dimethyl-1cyanoacetyl pyrazole $(0.82 \mathrm{~g}, 0.005 \mathrm{~mol})$ was refluxed in $15 \mathrm{~mL}$ dioxane for 4 hours. On cooling, the solid that formed was separated by filtration, dried and purified by recrystallization from EtOH. White crystals in 57\% yield; m.p. $=192-193{ }^{\circ} \mathrm{C}$, lit. m.p. $=191-193{ }^{\circ} \mathrm{C}$ [1]. IR: 3406, 3319, $3193(\mathrm{NH}, \mathrm{OH}), 2262(\mathrm{C} \equiv \mathrm{N}), 1695(\mathrm{C}=\mathrm{O}), 1641 \mathrm{~cm}^{-1}(\mathrm{C}=\mathrm{O}) ;{ }^{1} \mathrm{H}$ NMR (DMSO$d 6): \delta / \mathrm{ppm}=10.51(\mathrm{~s}, 1 \mathrm{H}), 8.73(\mathrm{~s}, 1 \mathrm{H}), 8.25(\mathrm{~s}, 1 \mathrm{H}), 7.87(\mathrm{~d}, J=8.80 \mathrm{~Hz}, 2 \mathrm{H}), 7.64(\mathrm{~d}, J=$ $8.80 \mathrm{~Hz}, 2 \mathrm{H}), 3.93(\mathrm{~s}, 2 \mathrm{H}), 3.65(\mathrm{~d}, J=4.60 \mathrm{~Hz}, 2 \mathrm{H})$; MS: m/z $(\%)=261$ (molecular ion peak, 32), 187 (base peak, 100); Analysis for $\mathrm{C}_{12} \mathrm{H}_{11} \mathrm{~N}_{3} \mathrm{O}_{4}$ (261.24): Calcd. C, 55.17; H, 4.24; $\mathrm{N}$, $16.09 \%$. Found: C, 54.98; H, 4.28; N, 16.22\%.

2.9. Synthesis of 2-[4-(2-cyanoacetamido)phenyl]-4-(4-methoxybenzylidene)-oxazol-5(4H)one (14).

A suspension of cyanoacetamide derivative $13(0.52 \mathrm{~g}, 0.002 \mathrm{~mol})$, anhydrous sodium acetate $(0.16 \mathrm{~g}, 0.002 \mathrm{~mol})$ and $p$-anisaldehyde $(0.27 \mathrm{~mL}, 0.002 \mathrm{~mol})$ in acetic anhydride $(20$ $\mathrm{mL}$ ) was heated at $100^{\circ} \mathrm{C}$ with stirring for 4 hours. After cooling, the reaction mixture was poured on ice-cold water. Then, the solid that obtained was filtered and recrystallized from EtOH. Brown crystals in 30\% yield; m.p. $=215-217^{\circ} \mathrm{C}$; IR: $3353(\mathrm{NH}), 2213(\mathrm{C} \equiv \mathrm{N}), 1748$ $(\mathrm{C}=\mathrm{O}), 1698(\mathrm{C}=\mathrm{O}), 1641 \mathrm{~cm}^{-1}(\mathrm{C}=\mathrm{N}) ;{ }^{1} \mathrm{H} \mathrm{NMR}\left(\mathrm{DMSO}-d_{6}\right): \delta / \mathrm{ppm}=9.45(\mathrm{~s}, 1 \mathrm{H}), 7.80-6.90$ $(\mathrm{m}, 9 \mathrm{H}), 3.90$ (s, 2H), 3.80 (s, 3H); Analysis for $\mathrm{C}_{20} \mathrm{H}_{15} \mathrm{~N}_{3} \mathrm{O}_{4}$ (361.36): Calcd. C, 66.48; H, $4.18 ; \mathrm{N}, 11.63 \%$. Found: C, 66.32; H, 4.25; N, $11.71 \%$.

\subsection{Synthesis of 4-[2-cyano-3-(4-tolyl)-acrylamido]-benzoyl-glycine (15).}

A mixture of cyanoacetamide compound $13(1.30 \mathrm{~g}, 0.005 \mathrm{~mol})$ with $p$-tolualdehyde $(0.60 \mathrm{ml}, 0.005 \mathrm{~mol})$ was refluxed in $20 \mathrm{~mL}$ of ethyl alcohol containing three drops of piperidine for 2 hours. The reaction mixture was left aside to cool, and the white crystals that formed was picked up by filtration and recrystallized from EtOH. White crystals in $66 \%$ yield; m.p. $=220-222^{\circ} \mathrm{C}$; IR: 3321, 3212, $3157(\mathrm{NH}$ and $\mathrm{OH}), 2214(\mathrm{C} \equiv \mathrm{N}), 1683(\mathrm{C}=\mathrm{O}), 1649 \mathrm{~cm}^{-1}$ $(\mathrm{C}=\mathrm{O}) ;{ }^{1} \mathrm{H}$ NMR (hot DMSO- $\left.d_{6}\right): \delta / \mathrm{ppm}=8.28(\mathrm{~s}, 1 \mathrm{H}), 8.05-7.15$ (four doublets, $\left.8 \mathrm{H}\right), 3.66(\mathrm{~d}$, $\mathrm{J}=4.80 \mathrm{~Hz}, 2 \mathrm{H}), 2.35$ (s, 3H); Analysis for $\mathrm{C}_{20} \mathrm{H}_{17} \mathrm{~N}_{3} \mathrm{O}_{4}$ (363.37): Calcd. C, 66.11; H, 4.72; N, $11.56 \%$. Found: C, 66.24; H, 4.70; N, 11.50\%.

2.11. Synthesis of 2-[4-(2-cyano-3-(4-tolyl)acrylamido)phenyl]-4-(4-methoxybenzylidene)oxazol-5(4H)-one (16).

A mixture of anhydrous sodium acetate $(0.16 \mathrm{~g}, 0.002 \mathrm{~mol})$, cyanoacrylamide compound 15 (0.76 g, $0.002 \mathrm{~mol})$ and $p$-anisaldehyde $(0.27 \mathrm{ml}, 0.002 \mathrm{~mol})$ in $15 \mathrm{~mL}$ acetic anhydride was heated with stirring at $100{ }^{\circ} \mathrm{C}$ for 4 hours. After cooling, the reaction mixture was poured on ice-cold water. Then, the solid that formed was filtered off and purified by recrystallization from EtOH. Yellow powder in 35\% yield; m.p. $=280-282^{\circ} \mathrm{C}$; IR: $3352(\mathrm{NH})$, $2213(\mathrm{C} \equiv \mathrm{N}), 1741(\mathrm{C}=\mathrm{O}), 1692 \mathrm{~cm}^{-1}(\mathrm{C}=\mathrm{O}) ;{ }^{1} \mathrm{H}$ NMR (DMSO-d $): \delta / \mathrm{ppm}=10.55(\mathrm{~s}, 1 \mathrm{H})$, $8.23(\mathrm{~s}, 1 \mathrm{H}), 8.04-7.15(\mathrm{~m}, 13 \mathrm{H}), 3.87(\mathrm{~s}, 3 \mathrm{H}), 2.31(\mathrm{~s}, 3 \mathrm{H})$; Analysis for $\mathrm{C}_{28} \mathrm{H}_{21} \mathrm{~N}_{3} \mathrm{O}_{4}$ (463.49): Calcd. C, 72.56; H, 4.57; N, 9.07\%. Found: C, 72.39; H, 4.73; N, 9.25\%. 


\subsection{Synthesis of 4-[2-cyano-2-(4-tolylhydrazono)-acetamido]-benzoyl-glycine (17).}

To a cold suspension of $p$-toluidine $(0.54 \mathrm{~g}, 0.005 \mathrm{~mol})$ in $1.5 \mathrm{~mL}$ conc. $\mathrm{HCl}$, a solution of $\mathrm{NaNO}_{2}\left(0.35 \mathrm{~g}\right.$ in $5 \mathrm{~mL}$ water) was added dropwise with continuous stirring at $0-5^{\circ} \mathrm{C}$. The prepared diazonium chloride solution was then added dropwise to a cold and stirred solution of cyanoacetamide compound $13(1.30 \mathrm{~g}, 0.005 \mathrm{~mol})$ and sodium acetate $(1.5 \mathrm{~g})$ in $30 \mathrm{~mL}$ ethyl alcohol. After stirring of the reaction mixture for 3 hours at $0-5^{\circ} \mathrm{C}$, the precipitate was filtered off and purified by heating in EtOH. Brown crystals in $74 \%$ yield; m.p. $=165-167^{\circ} \mathrm{C}$; IR: 3395 , $3230(\mathrm{NH}$ and $\mathrm{OH}), 2215(\mathrm{C} \equiv \mathrm{N}), 1683(\mathrm{C}=\mathrm{O}), 1646 \mathrm{~cm}^{-1}(\mathrm{C}=\mathrm{O}) ; 1 \mathrm{H}$ NMR (DMSO- $\left.d_{6}\right): \delta / \mathrm{ppm}$ $=12.25(\mathrm{~s}, 1 \mathrm{H}), 11.10(\mathrm{~s}, 1 \mathrm{H}), 9.65(\mathrm{~s}, 1 \mathrm{H}), 8.90(\mathrm{~s}, 1 \mathrm{H}), 7.75-7.30(\mathrm{~m}, 8 \mathrm{H}), 3.71(\mathrm{~d}, J=4.80$ $\mathrm{Hz}, 2 \mathrm{H}), 2.35$ (s, 3H); MS: m/z (\%) = 379 (molecular ion peak, 18.30), 65 (base peak, 100); Analysis for $\mathrm{C}_{19} \mathrm{H}_{17} \mathrm{~N}_{5} \mathrm{O}_{4}$ (379.38): Calcd. C, 60.15; H, 4.52; N, 18.46\%. Found: C, 60.29; H, $4.48 ; \mathrm{N}, 18.36 \%$.

\subsection{Synthesis of 2-[4-(2-cyano-(4-tolylhydrazono)-acetamido)-phenyl]-4-(4-methoxy-} benzylidene)- oxazol-5(4H)-one (18).

A mixture of anhydrous sodium acetate $(0.16 \mathrm{~g}, 0.002 \mathrm{~mol})$ and $p$-anisaldehyde $(0.27$ $\mathrm{ml}, 0.002 \mathrm{~mol})$, cyanoacetamide compound $17(0.75 \mathrm{~g}, 0.002 \mathrm{~mol})$ in $15 \mathrm{~mL}$ acetic anhydride was heated at $100^{\circ} \mathrm{C}$ for 4 hours. After cooling, the reaction mixture was poured on ice-cold water. Then, the solid that produced was picked up by filtration and purified by recrystallization from hot EtOH. Dark red crystals in $45 \%$ yield; m.p. $=231-233{ }^{\circ} \mathrm{C}$; IR: $3393(\mathrm{NH}), 2214$ $(\mathrm{C} \equiv \mathrm{N}), 1785(\mathrm{C}=\mathrm{O}), 1681 \mathrm{~cm}^{-1}(\mathrm{C}=\mathrm{O}) ;{ }^{1} \mathrm{H}$ NMR (DMSO- $\left.d_{6}\right): \delta / \mathrm{ppm}=11.45(\mathrm{~s}, 1 \mathrm{H}), 10.20(\mathrm{~s}$, $1 \mathrm{H}), 7.92-6.90(\mathrm{~m}, 13 \mathrm{H}), 3.82(\mathrm{~s}, 3 \mathrm{H}), 2.32(\mathrm{~s}, 3 \mathrm{H}) ; \mathrm{MS}: \mathrm{m} / \mathrm{z}(\%)=479$ (molecular ion peak, 12.30), 43 (base peak, 100); Analysis for $\mathrm{C}_{27} \mathrm{H}_{21} \mathrm{~N}_{5} \mathrm{O}_{4}$ (479.50): Calcd. C, 67.63; H, 4.41; N, 14.61\%. Found: C, 67.47; H, 4.49; N, 14.46\%.

\subsection{Anticancer screening.}

For the estimation of the cytotoxicity effects of the investigated oxazolone scaffolds, four human cancer cell lines were used (namely, hepatocellular carcinoma HepG-2, colorectal carcinoma HCT-116, human prostate cancer PC-3 and mammary gland breast cancer MCF-7). These cell lines were obtained from ATCC via Holding company for biological products and vaccines (VACSERA), Cairo, Egypt. Cytotoxicity determinations are based on the transformation of the yellow 3-(4,5-dimethylthiazol-2-yl)-2,5-diphenyl tetrazolium bromide (MTT) to a purple formazan derivative by mitochondrial succinate dehydrogenase in practical cells. The method of this MTT test was performed as previously described in detail [38-40].

\section{Results and Discussion}

\subsection{Chemistry.}

Condensation of $p$-aminohippuric acid (1) with different substituted aromatic aldehydes yielded the corresponding 4-(arylideneamino-benzoyl)-glycine derivatives 2a-e (Scheme 1), which were analyzed and secured by their compatible IR, ${ }^{1} \mathrm{H}$ NMR and elemental analysis. The IR spectrum of $\mathbf{2 a}$ (as an example) revealed the characteristic absorptions of ( $\mathrm{NH} \& \mathrm{OH}$ ) and carbonyl groups at 3318 and $1744 \mathrm{~cm}^{-1}$, respectively. The ${ }^{1} \mathrm{H}$ NMR spectrum of $\mathbf{2 b}$ exhibited three singlet signals for the protons of $\mathrm{OH}, \mathrm{NH}$ and $\mathrm{CH}=\mathrm{N}$ function at 12.30, 10.25 and 8.25 ppm, respectively, multiplet for the aromatic protons (7.80-7.25 ppm), doublet for two protons 
at $3.65 \mathrm{ppm}\left(-\mathrm{CH}_{2}-\right)$ and singlet for three protons at $2.35 \mathrm{ppm}\left(-\mathrm{CH}_{3}\right)$. Then, the formation of 2-(4-arylideneamino)-phenyl)-4-(4-methoxybenzylidene)-oxazol-5(4H)-ones 3a-e were achieved by classical Erlenmeyer reaction [41] that involve heating of compounds 2a-e with $p$-anisaldehyde at $100^{\circ} \mathrm{C}$ in acetic anhydride and sodium acetate. The IR spectrum of 3a revealed the characteristic absorption band of the carbonyl group of the oxazolone ring at 1793 $\mathrm{cm}^{-1}$. The reaction of $p$-aminohippuric acid (1) with phenyl isothiocyanate has been previously reported in the literature [42] to afford 4-(3-phenylthioureido)-benzoyl-glycine (4), which was utilized in the synthesis of 4-(4-methoxybenzylidene)-2-(4- $N$ '-phenylthioureido-phenyl)oxazol-5(4H)-one (5) by classical Erlenmeyer reaction. The reaction involves heating of 4 with $p$-anisaldehyde at $100{ }^{\circ} \mathrm{C}$ in acetic anhydride and sodium acetate. The spectral data (IR and ${ }^{1} \mathrm{H}$ NMR) has been utilized to establish the proposed structure of $\mathbf{5}$. In the infrared spectrum of $\mathbf{5}$, the $\mathrm{NH}$ and carbonyl functional groups were absorbed in 3387 and $1781 \mathrm{~cm}^{-1}$, respectively. ${ }^{1} \mathrm{H}$ NMR spectrum exhibited two singlet signals for the protons of NH functions at 13.25 and 11.75 ppm, multiplet for the aromatic and olefinic protons (7.95-7.24 ppm) and singlet for three protons at $3.79 \mathrm{ppm}\left(\mathrm{OCH}_{3}\right)$.
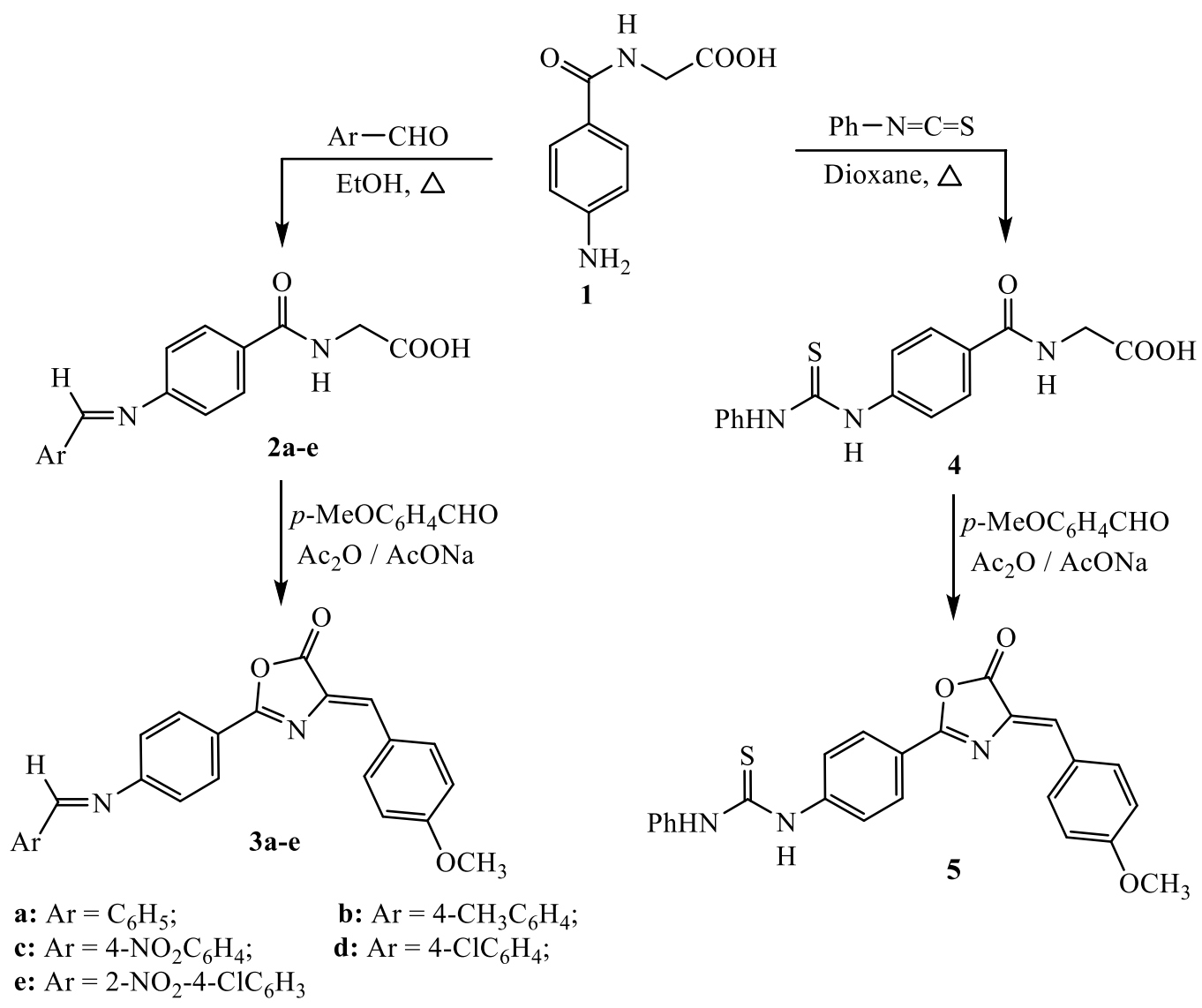

c: $\mathrm{Ar}=4-\mathrm{NO}_{2} \mathrm{C}_{6} \mathrm{H}_{4} ;$
e: $\mathrm{Ar}=2-\mathrm{NO}_{2}-4-\mathrm{ClC}_{6} \mathrm{H}_{3}$

Scheme 1. Synthesis of 2-(4-substitutedamino-phenyl)-4-(4-methoxybenzylidene)-oxazol-5(4H)-ones 3 and 5.

In addition, 4-[2-(dicyanomethylene)hydrazinyl]benzoyl-glycine (7) has been synthesized in $76 \%$ yield by diazotization of $p$-aminohippuric acid at $0-5^{\circ} \mathrm{C}$ with sodium nitrite and hydrochloride acid followed by diazo coupling with malononitrile as active methylene component in ethyl alcohol buffered with sodium acetate (Scheme 2). The characteristic NH and $\mathrm{OH}$ functions (IR spectrum of 7) absorbed at 3395 and $3222 \mathrm{~cm}^{-1}$. In comparison, absorptions at 2226 and $1753 \mathrm{~cm}^{-1}$ indicated the presence of nitrile and carbonyl groups, respectively. ${ }^{1} \mathrm{H}$ NMR spectrum showed singlet for the carboxylic proton at $12.25 \mathrm{ppm}$, two singlet signals for the protons of NH functions at 11.10 and $8.90 \mathrm{ppm}$, two doublet signals for 
the aromatic protons at 7.95 and $7.70 \mathrm{ppm}$ and doublet for the methylene protons at $3.68 \mathrm{ppm}$. Synthesis of our target 2-[4-(dicyanomethylene-hydrazinyl)-phenyl]-4-(4methoxybenzylidene)-oxazol-5(4H)-one (8) has been achieved by the application of classical Erlenmeyer method, involving condensation of benzoyl glycine derivative 7 with $p$ anisaldehyde in acetic anhydride and sodium acetate by heating at $100{ }^{\circ} \mathrm{C}$. The IR spectrum of 8 indicated absorptions at $3226 \mathrm{~cm}^{-1}$ for the NH function, $2224 \mathrm{~cm}^{-1}$ for the nitrile group, and $1788 \mathrm{~cm}^{-1}$ for the carbonyl group (oxazolone ring). ${ }^{1} \mathrm{H}$ NMR spectrum displayed singlet for hydrazone proton at $10.58 \mathrm{ppm}$, multiplet for the aromatic and olefinic protons at 7.96-7.13 ppm, and singlet for the methoxy protons at $3.86 \mathrm{ppm}$. In addition, 4-[(2-amino-4phenylthiazol-5-yl)azo]benzoyl-glycine (10) was synthesized in good yield (\%80) by diazotization of 1 with sodium nitrite at $0-5^{\circ} \mathrm{C}$ and hydrochloric acid followed by diazo coupling with 2-amino-4-phenylthiazole (9) in ethanol buffered by sodium acetate solution. The IR spectrum of $\mathbf{1 0}$ exhibited broad absorption bands for the $\mathrm{NH}_{2}, \mathrm{NH}$, and $\mathrm{OH}$ groups centered at 3402 and $3337 \mathrm{~cm}^{-1}$ and broad absorption at $1627 \mathrm{~cm}^{-1}$ indicating the carbonyl function. The formation of 2-[4-(2-acetylamino-4-phenylthiazol-5-yl)azo-phenyl]-4-(4methoxybenzylidene)-oxazol-5(4H)-one (11) was achieved by condensation of 5arylazothiazole derivative $\mathbf{1 0}$ with $p$-anisaldehyde in acetic anhydride and sodium acetate at $100^{\circ} \mathrm{C}$. The proposed structure of $\mathbf{1 1}$ was elucidated by spectral analyses (IR and ${ }^{1} \mathrm{H}$ NMR). The infrared spectrum of $\mathbf{1 1}$ exhibited the absorption of NH group at $3162 \mathrm{~cm}^{-1}$ and absorptions due to two carbonyl functions at 1772 (oxazolone ring) and $1684 \mathrm{~cm}^{-1}$ (amide). ${ }^{1} \mathrm{H}$ NMR spectrum displayed singlet for the proton of $\mathrm{NH}$ at $12.68 \mathrm{ppm}$, multiplet for the aromatic and olefinic protons in the region 8.24-7.21 ppm, and two singlet signals for the protons of methoxy and methyl groups at 3.80 and $2.23 \mathrm{ppm}$.

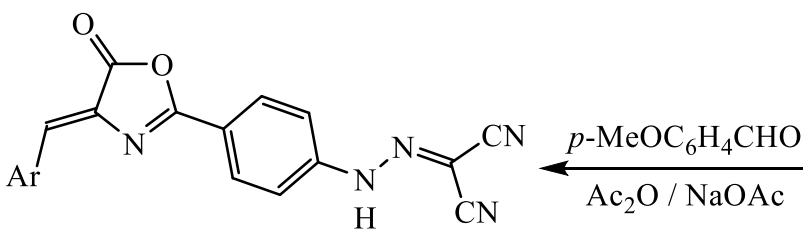

8: $\mathrm{Ar}=4-\mathrm{MeOC}_{6} \mathrm{H}_{4}$<smiles>Nc1ccc(C(=O)NCC(=O)O)cc1</smiles><smiles>CC(=O)Nc1nc(-c2ccccc2)c(/N=N/c2ccc(C3=N/C(=C\[Al])C(=O)O3)cc2)s1</smiles>

11: $\mathrm{Ar}=4-\mathrm{MeOC}_{6} \mathrm{H}_{4}$<smiles>N#CC(C#N)=NNc1ccc(C(=O)NCC(=O)O)cc1</smiles><smiles>CCCCCCC(C)C(=O)ON</smiles><smiles>O=C(O)CNC(=O)c1ccc(N=[W])cc1</smiles>

6<smiles>CCCC(C)O</smiles>

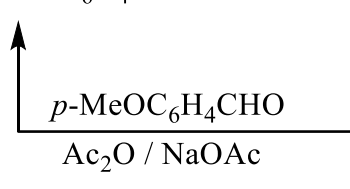<smiles>Nc1nc(-c2ccccc2)c(/N=N/c2ccc(C(=O)NCC(=O)O)cc2)s1</smiles>

10

Scheme 2. Synthesis of 4-(4-methoxybenzylidene)-2-[4-substituted-azophenyl]-oxazol-5(4H)-ones 8 and 11. 
The formation of cyanoacetamide scaffolds has been achieved by different methods. The literature provided several methods to prepare many $N$-aryl or $N$-heteroarylcyanoacetamides $[43,44]$. Cyanoacetyl pyrazole, which was synthesized by Ried et al. [45], is a very handily and successfully utilized for the preparation of many $\mathrm{N}$-alkyl and $\mathrm{N}$-aryl cyanoacetamide compounds. Thus, cyanoacetylation of $p$-aminohippuric acid was achieved by heating with 3,5-dimethyl-1-cyanoacetyl pyrazole in dioxane to furnish the corresponding $p$ $(N$-cyanoacetylamino)-hippuric acid (13) (Scheme 3 ). Heterocyclization of cyanoacetamide derivative 13 into our target oxazolone was achieved by condensation with $p$-anisaldehyde in acetic anhydride and sodium acetate at $100^{\circ} \mathrm{C}$ to furnish 2-[4-(2-cyanoacetamido)phenyl]-4(4-methoxybenzylidene)-oxazol-5(4H)-one (14). The IR spectrum of 14 revealed absorption bands of $\mathrm{NH}$ and nitrile functions at 3353 and $2213 \mathrm{~cm}^{-1}$, in addition to absorption bands of two carbonyl groups $(\mathrm{C}=\mathrm{O})$ at 1748 and $1698 \mathrm{~cm}^{-1} .{ }^{1} \mathrm{H} \mathrm{NMR}$ spectrum exhibited singlet for the proton of $\mathrm{NH}$ function at $9.45 \mathrm{ppm}$, multiplet for the aromatic and olefinic protons in the region 7.80-6.90 ppm, and two singlet signals for the protons of $-\mathrm{CH}_{2}-$ and $-\mathrm{OCH}_{3}$ at 3.90 and 3.80 ppm, respectively.<smiles>Nc1ccc(C(=O)NCC(=O)O)cc1</smiles>

1

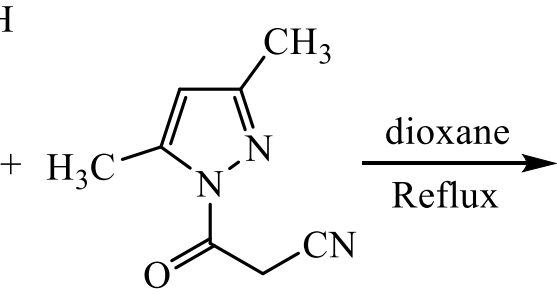

12

14: $\mathrm{Ar}=4-\mathrm{MeOC}_{6} \mathrm{H}_{4}$<smiles>N#CCC(=O)Nc1ccc(C(=O)NCC(=O)O)cc1</smiles>

13<smiles>N#CCC(=O)Nc1ccc(C2=N/C(=C\[Al])C(=O)O2)cc1</smiles>

Scheme 3. Synthesis of 2-[4-(2-cyanoacetamido)phenyl]-4-(4-methoxybenzylidene)-oxazol-5(4H)-one (14).

In addition, 4-[2-cyano-3-(4-tolyl)-acrylamido]benzoyl-glycine (15) has been formed by condensation of compound $\mathbf{1 3}$ with $p$-tolualdehyde by heating under reflux in ethanol containing drops of piperidine (Scheme 4). IR and ${ }^{1} \mathrm{H}$ NMR spectral analyses have been employed to elucidate the proposed structure of 15. In the IR spectrum, $\mathrm{NH}$ and $\mathrm{OH}$ groups absorbed at 3321, 3212, and $3157 \mathrm{~cm}^{-1}$, nitrile group absorbed at $2214 \mathrm{~cm}^{-1}$ while absorptions of the two carbonyl groups $(\mathrm{C}=\mathrm{O})$ were recognized at 1683 and $1649 \mathrm{~cm}^{-1} .{ }^{1} \mathrm{H}$ NMR spectrum showed singlet for the olefinic proton $(\mathrm{C}=\mathrm{CH})$ at $8.28 \mathrm{ppm}$, four doublet signals for the aromatic protons $(8.05-7.15 \mathrm{ppm})$, doublet for two protons at $3.66 \mathrm{ppm}\left(-\mathrm{CH}_{2}-\right)$ and singlet for three protons at $2.35 \mathrm{ppm}\left(-\mathrm{CH}_{3}\right)$. After that, 2-[4-(2-cyano-3-(4-tolyl)acrylamido)phenyl]- 4(4-methoxybenzylidene)-oxazol-5(4H)-one (16) was prepared by classical Erlenmeyer method, involving heating of the unsaturated nitrile scaffold 15 with $p$-anisaldehyde in acetic anhydride and sodium acetate at $100{ }^{\circ} \mathrm{C}$. The ${ }^{1} \mathrm{H}$ NMR spectrum of oxazolone 16 showed singlet for the proton of $\mathrm{NH}$ function at $10.55 \mathrm{ppm}$, singlet for one olefinic proton at $8.23 \mathrm{ppm}$, multiplet for the aromatic and olefinic protons in the region $8.04-7.15 \mathrm{ppm}$ and two singlet 
signals for the protons of methoxy and methyl groups at 3.87 and $2.31 \mathrm{ppm}$, respectively. The reactivity of the methylene group of cyanoacetamide derivative $\mathbf{1 3}$ has been examined towards electrophilic diazo coupling reaction. Thus, diazo coupling reaction of cyanoacetamide derivative 13 with $p$-tolyl diazonium chloride at $0-5^{\circ} \mathrm{C}$ in ethanol buffered with sodium acetate solution furnished 4-[2-cyano-2-(4-tolylhydrazono)-acetamido]-benzoyl-glycine (17). The ${ }^{1} \mathrm{H}$ NMR spectrum showed singlet for the carboxylic proton at $12.25 \mathrm{ppm}$, three singlet signals for the protons of $\mathrm{NH}$ functions at $11.10,9.65$ and $8.90 \mathrm{ppm}$, multiplet for the aromatic protons (7.75-7.30 ppm), doublet for the methylene protons at $3.71 \mathrm{ppm}$ and singlet for three protons of the methyl group at $2.35 \mathrm{ppm}$. Finally, the synthesis of 2-[4-(2-cyano-(4-tolylhydrazono)acetamido)-phenyl]- 4-(4-methoxy-benzylidene)-oxazol-5(4H)-one (18) was achieved by heating of 17 with $p$-anisaldehyde in acetic anhydride and sodium acetate at $100^{\circ} \mathrm{C}$. The IR spectrum of 18 displayed the absorptions of $\mathrm{NH}$ function at $3393 \mathrm{~cm}^{-1}$ and cyano function at $2214 \mathrm{~cm}^{-1}$ in addition to two absorptions 1785 and $1681 \mathrm{~cm}^{-1}$ for the carbonyl groups. In the ${ }^{1} \mathrm{H}$ NMR spectrum, the protons of NH groups resonated as two singlet signals at 11.45 and $10.20 \mathrm{ppm}$. The multiplet in the region 7.92-6.90 ppm indicated the aromatic and olefinic protons. In comparison, the protons of $-\mathrm{OCH}_{3}$ and $-\mathrm{CH}_{3}$ groups resonated as two singlet signals at 3.82 and $2.32 \mathrm{ppm}$.

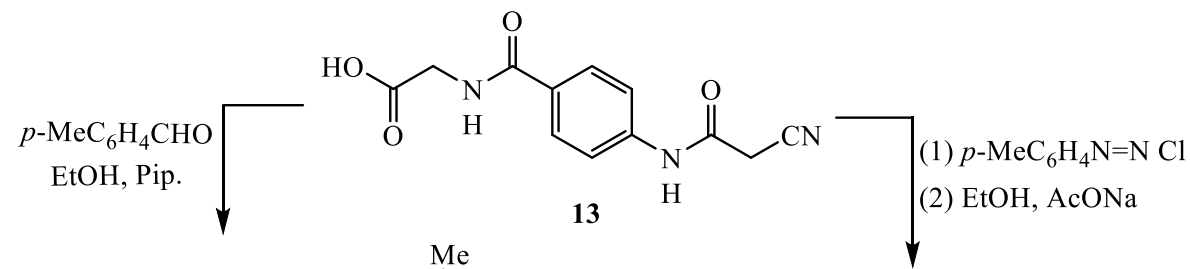<smiles>Cc1ccc(/C=C(/C#N)C(=O)Nc2ccc(C(=O)NCC(=O)O)cc2)cc1</smiles><smiles>[3H]/C=C1/N=C(c2ccc(NC(=O)/C(C#N)=C\c3ccc(C)cc3)cc2)OC1=O</smiles>

16: $\mathrm{Ar}=4-\mathrm{MeOC}_{6} \mathrm{H}_{4}$<smiles>CS(=O)(=O)c1ccc(N/N=C(/C#N)C(=O)Nc2ccc(C(=O)NCC(=O)O)cc2)cc1</smiles>

17

$$
\begin{aligned}
& p \text {-Anisaldehyde } \\
& \mathrm{Ac}_{2} \mathrm{O} / \mathrm{NaOAc}
\end{aligned}
$$

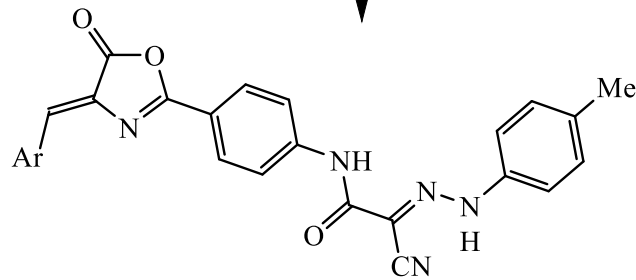

18: $\mathrm{Ar}=4-\mathrm{MeOC}_{6} \mathrm{H}_{4}$

Scheme 4. Synthesis of 2-[4-(substituted-2-cyanoacetamido)-phenyl]-4-(4-methoxybenzylidene)oxazol-5(4H)ones 16 and 18.

\subsection{In vitro anticancer activity.}

The pharmacological activities of oxazolone compound 3a-e, 5, 8, 11, 14, 16 and 18 were performed against four types of human cancer cell lines: HepG2 (hepatocellular carcinoma), HTC-116 (colorectal carcinoma), PC-3 (prostate cancer) and MCF-7 (mammary gland breast cancer). As seen in Table 1, the majority of the synthesized oxazolone scaffolds reveal moderate to strong cytotoxic effects toward the four tested human cancer cell lines. The 
oxazolone compound $\mathbf{3 e}$ exhibited the highest cytotoxic effect against two of the tested cell lines HepG2 (IC50 8.9 $\pm 0.30 \mu \mathrm{g} / \mathrm{mL}$ ) and HTC-116 (IC50 $9.2 \pm 0.63 \mu \mathrm{g} / \mathrm{mL}$ ), their IC50 values were near to the standard anticancer drug 5-fluorouracil (5-FU). These promising results may be attributed to the presence of electron-withdrawing groups (chlorine and nitro) at the phenyl moiety. Besides, it showed strong cytotoxic effects among the other two cancer cell lines PC$3\left(\mathrm{IC}_{50} 13.1 \pm 1.06 \mu \mathrm{g} / \mathrm{mL}\right)$ and MCF-7 $\left(\mathrm{IC}_{50} 12.1 \pm 1.06 \mu \mathrm{g} / \mathrm{mL}\right)$. Furthermore, against all tested cancer cell lines, the oxazolone compound $\mathbf{1 8}$ was found to show strong cytotoxic effects. In contrast, the oxazolone compounds $\mathbf{3 d}, \mathbf{5}$, and $\mathbf{1 4}$ exhibited moderate cytotoxic effects.

Table 1. Cytotoxicity data of the prepared oxazolone scaffolds against human tumor cells.

\begin{tabular}{l|c|c|c|c}
\multirow{2}{*}{ Compound No. } & \multicolumn{4}{|c}{ In vitro Cytotoxicity IC50 $(\boldsymbol{\mu g} / \mathbf{m L})$} \\
\cline { 2 - 5 } & HepG2 & HCT-116 & PC-3 & MCF-7 \\
\hline $\mathbf{5 - F U}$ & $7.91 \pm 0.28$ & $5.20 \pm 0.14$ & $8.30 \pm 0.25$ & $5.51 \pm 0.21$ \\
\hline $\mathbf{3 a}$ & $70.5 \pm 4.83$ & $61.8 \pm 4.85$ & $47.5 \pm 3.69$ & $59.0 \pm 4.30$ \\
\hline $\mathbf{3 b}$ & $81.5 \pm 5.60$ & $86.2 \pm 5.07$ & $92.5 \pm 6.11$ & $89.6 \pm 5.38$ \\
\hline $\mathbf{3 c}$ & $47.7 \pm 4.67$ & $51.9 \pm 4.39$ & $67.7 \pm 4.96$ & $62.4 \pm 4.31$ \\
\hline $\mathbf{3 d}$ & $16.4 \pm 1.63$ & $20.0 \pm 1.67$ & $27.3 \pm 2.32$ & $30.8 \pm 2.90$ \\
\hline $\mathbf{3 e}$ & $8.9 \pm 0.30$ & $9.2 \pm 0.63$ & $13.1 \pm 1.06$ & $12.1 \pm 1.06$ \\
\hline $\mathbf{5}$ & $25.8 \pm 1.35$ & $19.2 \pm 1.32$ & $29.9 \pm 1.98$ & $33.5 \pm 2.87$ \\
\hline $\mathbf{8}$ & $73.0 \pm 5.31$ & $80.9 \pm 5.67$ & $82.3 \pm 4.69$ & $87.4 \pm 5.21$ \\
\hline $\mathbf{1 1}$ & $62.3 \pm 3.96$ & $55.4 \pm 4.31$ & $71.3 \pm 4.37$ & $85.4 \pm 4.87$ \\
\hline $\mathbf{1 4}$ & $22.6 \pm 2.08$ & $32.8 \pm 2.42$ & $33.2 \pm 2.63$ & $31.3 \pm 2.26$ \\
\hline $\mathbf{1 6}$ & $89.5 \pm 5.62$ & $93.1 \pm 6.37$ & $96.4 \pm 5.23$ & $92.9 \pm 5.65$ \\
\hline $\mathbf{1 8}$ & $14.7 \pm 1.48$ & $13.4 \pm 1.26$ & $15.9 \pm 1.55$ & $18.9 \pm 2.00$
\end{tabular}

\section{Conclusions}

New series of oxazolone scaffolds 3a-e, 5, 8, 11, 14, 16, and 18 were synthesized via application of Erlenmeyer reaction to p-substituted amino-hippuric acid derivatives. Most of the synthesized compounds exhibited moderate to strong cytotoxic effects toward the tested human cancer cell lines (HepG2, HTC-116, PC-3, and MCF-7). The best activity was obtained with compound 3e against hepatocellular carcinoma (IC50 $8.9 \pm 0.30 \mu \mathrm{g} / \mathrm{mL}$ ) and colorectal carcinoma ( $\mathrm{IC}_{50} 9.2 \pm 0.63 \mu \mathrm{g} / \mathrm{mL}$ ) cell lines compared with the standard anticancer drug 5fluorouracil, long or complex.

\section{Funding}

This research received no external funding.

\section{Acknowledgments}

This research has no acknowledgment.

\section{Conflicts of Interest}

The authors declare no conflict of interest.

\section{References}

1. Abdel-Galil, E.; Moawad, E.B.; El-Mekabaty, A.; Said, G.E. Synthesis and biological evaluation of new multifunctional oxazolone scaffolds incorporating phenyl benzoate moiety. J. Heterocycl. Chem. 2018, 55, 1092-1100, https://doi.org/10.1002/jhet.3139.

2. Tozzini, V.; Bizzarri, A.R.; Pellegrini, V.; Nifosì, R.; Giannozzi, P.; Iuliano, A.; Cannistraro, S.; Beltram, F. The low frequency vibrational modes of green fluorescent proteins. Chem. Phys. 2003, 287, 33-42, https://doi.org/10.1016/S0301-0104(02)00976-X. 
3. Ozturk, G.; Alp, S.; Timur, S. Photophysical characterization of fluorescent oxazol-5-one derivatives in PVC and their application as biosensors in the detection of ACh and AChE inhibitor: Donepezil. Dyes Pigment 2008, 76, 792-798, https://doi.org/10.1016/j.dyepig.2007.02.005.

4. Aguirre-Rentería, S.A.; Carrizales-Castillo, J.J.; Corona, M.D.R.C.; Hernández-Fernández, E.; GarzaGonzález, E.; Rivas-Galindo, V.M.; Arredondo-Espinoza, E.; Avalos-Alanís, F.G. Synthesis and in vitro evaluation of antimycobacterial and cytotoxic activity of new $\alpha, \beta$-unsaturated amide, oxazoline and oxazole derivatives from L-serine. Bioorg. Med. Chem. Lett. 2020, 30, https://doi.org/10.1016/j.bmcl.2020.127074.

5. Anh, D.T.; Hai, P.T.; Park, E.J.; Jun, H.W.; Kang, J.S.; Kwon, J.H.; Anh, V.T.; Han, S.B.; Nam, N.H.; Exploration of certain 1,3-oxazole-and 1,3-thiazole-based hydroxamic acids as histone deacetylase inhibitors and antitumor agents. Bioorg. Chem. 2020, 101, https://doi.org/10.1016/j.bioorg.2020.103988.

6. Rahim, F.; Tariq, S.; Taha, M.; Ullah, H.; Zaman, K.; Uddin, I.; Wadood, A.; Khan, A.A.; Rehman, A.U.; Uddin, N.; Zafar, S. New triazinoindole bearing thiazole/oxazole analogues: Synthesis, $\alpha$-amylase inhibitory potential and molecular docking study. Bioorg. Chem. 2019, 92, https://doi.org/10.1016/j.bioorg.2019.103284.

7. Zhang, H.Z.; Zhao, Z.L.; Zhou, C.H. Recent advance in oxazole-based medicinal chemistry. Eur. J. Med. Chem. 2018, 144, 444-492, https://doi.org/10.1016/j.ejmech.2017.12.044.

8. Abdel-Maksoud, M.S.; Ammar, U.M.; El-Gamal, M.I.; El-Din, M.M.G.; Mersal, K.I.; Ali, E.M.; Yoo, K.H.; Lee, K.T.; Oh, C.H. Design, synthesis, and anticancer activity of imidazo[2,1-b]oxazole-based RAF kinase inhibitors. Bioorg. Chem. 2019, 93, https://doi.org/10.1016/j.bioorg.2019.103349.

9. Rashamuse, T.J.; Harrison, A.T.; Mosebi, S.; van Vuuren, S.; Coyanis, E.M.; Bode, M.L. Design, synthesis and biological evaluation of imidazole and oxazole fragments as HIV-1 integrase-LEDGF/p75 disruptors and inhibitors of microbial pathogens. Bioorg. Med. Chem. 2020, 28, https://doi.org/10.1016/j.bmc.2019.115210.

10. Tangellamudi, N.D.; Shinde, S.B.; Pooladanda, V.; Godugu, C.; Balasubramanian, S. Facile synthesis of 2aryl 5-hydroxybenzo[d]oxazoles and their in vitro anti-proliferative effects on various cancer cell lines. Bioorg. Med. Chem. Lett. 2018, 28, 3639-3647, https://doi.org/10.1016/j.bmcl.2018.10.038.

11. Iyer, S.S.; Gensollen, T.; Gandhi, A.; Oh, S.F.; Neves, J.F.; Collin, F.; Lavin, R.; Serra, C.; Glickman, J.; de Silva, P.S.; Sartor, R.B. Dietary and microbial oxazoles induce intestinal inflammation by modulating aryl hydrocarbon receptor responses. Cell 2018, 173, 1123-1134, https://doi.org/10.1016/j.cell.2018.04.037.

12. Ye, F.; Zhai, Y.; Kang, T.; Wu, S.L.; Li, J.J.; Gao, S.; Zhao, L.X.; Fu, Y. Rational design, synthesis and structure-activity relationship of novel substituted oxazole isoxazole carboxamides as herbicide safener. Pestic. Biochem. Physio. 2019, 157, 60-68, https://doi.org/10.1016/j.pestbp.2019.03.003.

13. Bao, J.; Liu, H.; Zhi, Y.; Yang, W.; Zhang, J.; Lu, T.; Wang, Y.; Lu, S. Discovery of benzo[d]oxazole derivatives as the potent type-I FLT3-ITD inhibitors. Bioorg. Chem. 2020, 94, 103248, https://doi.org/10.1016/j.bioorg.2019.103248.

14. Yu, C.; Zhou, B.; Su, W.; Xu, Z. Erlenmeyer Synthesis for Azlactones Catalyzed by Ytterbium (III) Triflate under Solvent-Free Conditions. Synth. Commun. 2006, 36, 3447-3453, https://doi.org/10.1080/00397910600941521.

15. Pail, P.B.; Neculqueo, G.W.; Maccari, G.P.; Chagastelles, P.C.; Freitas, R.D.; Dagnino, A.P.; Campos, M.M. The role of kinin $\mathrm{B}_{1}$ and $\mathrm{B}_{2}$ receptors in the mouse model of oxazolone-induced atopic dermatitis. Int. immunopharmacol. 2019, 72, 62-73, https://doi.org/10.1016/j.intimp.2019.03.063.

16. Moner, V.; Fernández, E.; Calpena, A.C.; Garcia-Herrera, A.; Cócera, M.; López, O. A lamellar body mimetic system for the treatment of oxazolone-induced atopic dermatitis in hairless mice. J. Dermatol. Sci. 2018, 90, 172-179, https://doi.org/10.1016/j.jdermsci.2018.01.010.

17. Jung, Y.; Kim, J.C.; Park, N.J.; Bong, S.K.; Lee, S.; Jegal, H.; Jin, L.T.; Kim, S.M.; Kim, Y.K.; Kim, S.N. Eupatilin, an activator of PPAR $\alpha$, inhibits the development of oxazolone-induced atopic dermatitis symptoms in Balb/c mice. Biochem. Biophys. Res. Commun., 2018, 496, 508-514, https://doi.org/10.1016/j.bbrc.2018.01.098.

18. Lee, S.; Park, N.J.; Bong, S.K.; Jegal, J.; Park, S.A.; Kim, S.N.; Yang, M.H. Ameliorative effects of Juniperus rigida fruit on oxazolone-and 2, 4-dinitrochlorobenzene-induced atopic dermatitis in mice. $J$. Ethnopharmacol. 2018, 214, 160-167, https://doi.org/10.1016/j.jep.2017.12.022.

19. Lee, S.; Jung, J.; Choi, J.; Piao, M.; Choi, D.; Lee, J.; 323 Natural antioxidant products from peanuts sprouts and citron seed oils exhibit a potent anti-inflammatory activity in the oxazolone-induced contact dermatitis model in vivo. J. Invest. Dermatol. 2019, 139, S56, https://doi.org/10.1016/j.jid.2019.03.399.

20. Aksoydan, B.; Kantarcioglu, I.; Erol, I.; Salmas, R.E.; Durdagi, S. Structure-based design of hERG-neutral antihypertensive oxazalone and imidazolone derivatives. J. Mol. Graph. Model. 2018, 79, 103-117, https://doi.org/10.1016/j.jmgm.2017.10.011.

21. Salgın-Gökşen, U.; Gökhan-Kelekçi, N.; Göktaş, Ö.; Köysal, Y.; Kılıç, E.; Işık, Ş.; Aktay, G.; Özalp, M. 1Acylthiosemicarbazides, 1,2,4-triazole-5(4H)-thiones, 1,3,4-thiadiazoles and hydrazones containing 5methyl-2-benzoxazolinones: synthesis, analgesic-anti-inflammatory and antimicrobial activities. Bioorg. Med. Chem. 2007, 15, 5738-5751, https://doi.org/10.1016/j.bmc.2007.06.006.

22. Jat, L.R.; Mishra, R.; Pathak, D. Synthesis and anticancer activity of 4-benzylidene-2-phenyloxazol-5 (4H)one derivatives. Int. J. Pharm. Pharm. Sci. 2012, 4, 378-380. 
23. Tsukumo, Y.; Harada, D.; Manabe, H. Pharmacological characterization of itch-associated response induced by repeated application of oxazolone in mice. J. Pharmacol. Sci. 2010, 113, 255-262, https://doi.org/10.1254/jphs.10050FP.

24. Perron-Sierra, F.M.; Pierre, A.; Burbridge, M.; Guilbaud, N. Novel bicyclic oxazolone derivatives as antiangiogenic agents. Bioorg. Med. Chem. Lett. 2002, 12, 1463-1466, https://doi.org/10.1016/S0960894X(02)00197-X.

25. Hamidian, H.; Azizi, S. Synthesis of novel compounds containing morpholine and 5(4H)-oxazolone rings as potent tyrosinase inhibitors., Bioorg. Med. Chem. 2015, 23, 7089-7094, https://doi.org/10.1016/j.bmc.2015.09.015.

26. Fadavi, A.; Zarei, M. One-pot Vilsmeier reagent-mediated multicomponent reaction: A direct synthesis of oxazolones and Erlenmeyer azlactones from carboxylic acids. C. R. Chim. 2018, 21, 9-13, https://doi.org/10.1016/j.crci.2017.12.001.

27. Fujii, A.; Matsuo, H.; Choi, J.C.; Fujitani, T.; Fujita, K.I. Efficient synthesis of 2-oxazolidinones and quinazoline-2,4(1H,3H)-diones from $\mathrm{CO}_{2}$ catalyzed by tetrabutylammonium fluoride. Tetrahedron 2018, 74, 2914-2920, https://doi.org/10.1016/j.tet.2018.04.059.

28. Yoneyama, H.; Oka, N.; Usami, Y.; Harusawa, S. A Novel synthetic method of 2,4-disubstituted oxazoles using carboxylic acid-derived $\mathrm{Bu}_{2} \mathrm{Sn}[\mathrm{OC}(\mathrm{O}) \mathrm{R}]_{2}$. Tetrahedron Lett. 2020, 61, https://doi.org/10.1016/j.tetlet.2020.151983.

29. Vchislo, N.V.; Fedoseeva, V.G.; Novokshonov, V.V.; Larina, L.I.; Rozentsveig, I.B.; Verochkina, E.A. Synthesis of new alkoxy/alkylthiovinylated oxazoles using tosylmethyl isocyanide. Mendeleev Commun. 2020, 30, 350-351, https://doi.org/10.1016/j.mencom.2020.05.030.

30. Rao, Y.S.; R. Filler, R. Geometric isomers of 2-aryl (aralkyl)-4-arylidene (alkylidene)-5(4H)-oxazolones Synthesis 1975, 12, 749-764, https://doi.org/10.1055/s-1975-23919.

31. Paul, S.; Nanda, P.; Gupta, R.; Loupy, A. Calcium acetate catalyzed synthesis of 4-arylidene-2-phenyl5(4H)-oxazolones under solvent-free conditions. Tetrahedron Lett. 2004, 45, 425-427, https://doi.org/10.1016/j.tetlet.2003.10.125.

32. Voosala, C.; Kilaru, P.S.; Dasari, U.K. A facile and efficient synthesis of 4-arylidene-2-phenyl-5(4H)oxazolones and their antimicrobial evaluation against selected human and phytopathogens. J. Chinese Chem. Soc. 2016, 63, 909-916, https://doi.org/10.1002/jccs.201600083.

33. Beccalli, E.M.; Clerici, F.; Gelmi, M.L.; 5(4H)-oxazolones. Part XIII. A new synthesis of 4-ylidene-5(4H)oxazolones by the Stille reaction. Tetrahedron 1999, 55, 781-786, https://doi.org/10.1016/S00404020(98)01070-9.

34. Pattarawarapan, M.; Jaita, S.; Phakhodee, W. A convenient synthesis of 4-arylidene-2-phenyl-5(4H)oxazolones under solvent-assisted grinding. Tetrahedron Lett. 2016, 57, 3171-3174, https://doi.org/10.1016/j.tetlet.2016.06.029.

35. Fozooni, S.; Tikdari, A.M.; Hamidian, H.; Khabazzadeh, H. A synthesis of some new 4-arylidene-5(4H)oxazolone azo dyes and an evaluation of their solvatochromic behavior. ARKIVOC 2008, 14, 115-123.

36. Al-Romaizan, A.N. Synthesis and antitumor activity of new isolated and fused heterobicyclic nitrogen systems containing 1,3,4-thiadiazole moiety derived from $N^{1}, N^{2}$-diaryl hydrazine compound. Lett. Appl. Bioscience 2020, 9, 885-891, https://doi.org/10.33263/LIANBS91.885891.

37. Kumari, R.; Mishra, R.C.; Yadav, J.P. Antioxidant and cytotoxic studies of Acacia nilotica twig extract and their green synthesized silver nanoparticles. Lett. Appl. Bioscience 2020, 9, 975-980, https://doi.org/10.33263/LIANBS92.975980.

38. Mosmann T. Rapid colorimetric assay for cellular growth and survival: application to proliferation and cytotoxicity assays. J. Immunol. Methods 1983, 65, 55-63, https://doi.org/10.1016/0022-1759(83)90303-4.

39. Denizot, F.; Lang, R. Rapid colorimetric assay for cell growth and survival: modifications to the tetrazolium dye procedure giving improved sensitivity and reliability. J. Immunol. Methods 1986, 89, 271-277, https://doi.org/10.1016/0022-1759(86)90368-6.

40. Mauceri, H.J.; Hanna, N.N.; Beckett, M.A.; Gorski, D.H.; Staba, M.J.; Stellato, K.A.; Bigelow, K.; Heimann, R.; Gately, S.; Dhanabal, M.; Soff, G.A. Combined effects of angiostatin and ionizing radiation in antitumour therapy. Nature 1998, 394, 287-291, https://doi.org/10.1038/28412.

41. Erlenmeyer, F. Ueber die Condensation der Hippursäure mit Phtalsäureanhydrid und mit Benzaldehyd Justus Liebigs Annalen Chem. 1893, 3, 275-282, https://doi.org/10.1002/jlac.18932750102.

42. Abbas, S.Y.; El-Sharief, M.A.S.; Basyouni, W.M.; Fakhr, I.M.; El-Gammal, E.W. Thiourea derivatives incorporating a hippuric acid moiety: Synthesis and evaluation of antibacterial and antifungal activities. Eur. J. Med. Chem. 2013, 64, 111-120, https://doi.org/10.1016/j.ejmech.2013.04.002.

43. Metwally, M.A.; Keshk, E.M.; Fekry, A.; Etman, H.A. Synthesis and reactions of 2-cyano-2-(5-oxo-3phenyl-thiazolidin-2-ylidene)-acetamides. J. Chem. Res. 2004, 602-604, https://doi.org/10.3184/0308234042430322.

44. Bhawal, B.M.; Khanapure, S.P.; Biehl, E.R. Rapid, low-temperature amidation of ethyl cyano-acetate with lithium amides derived from primary and secondary amines., Synth. Commun. 1990, 20, 3235-3243, https://doi.org/10.1080/00397919008051551. 
45. Ried, W.; Schleimer, B., Cyan-acethydrazid zur Darstellung von Stickstoff-Heterocyclen, II. 1-Acyl-3.5dimethyl-pyrazole als Acylierungsmittel. Angew. Chem. 1958, 70, 164-164, https://doi.org/10.1002/ange.19580700607. 